\title{
CHILDREN WITH REDUCED CogNITIVE EFFICIENCY AND AdDition OF NATURAL NumbERS UP TO 20: A CASE STUDY
}

IRENA BudíNOVÁ ${ }^{1} \&$ TOMÁš JANíK ${ }^{1}$

\section{Potrjeno/Accepted}

15. 3. 2021

Objavljeno/Published

21. 6. 2021

Keywords:

learning addition, pupils with learning difficulties in mathematics, cognitive efficiency, natural numbers, additive triad, case study

\section{Ključne besede:} učenje seštevanja, učenci z učnimi težavami pri matematiki, kognitivna učinkovitost, naravna števila, seštevalna triada, študija primera

UDK/UDC

373.3.091.3:51 20: študija primera
${ }^{1}$ Masaryk University, Faculty of Education, Brno, Czech Republic

\author{
CORRESPONDING AUTHOR/KORESPONDENČNI AVTOR \\ budinova@ped.muni.cz
}

\begin{abstract}
Izvleček The study deals with teaching and learning the addition of natural numbers up to 20 in the first two years of primary school. The first part presents the theoretical background for addition of natural numbers, the procedural and conceptual approach to addition, and the theory of the additive triad. The causes of the difficulties some children have with the field of the addition of natural numbers are outlined, and the issue of reduced cognitive efficiency is briefly introduced as one of the causes. The second part of the study presents a case study of a girl ( 7 years old) who experienced difficulty in learning addition. The approaches to and results of remedial tutoring completed by the girl are described. In the discussion, the issue of the addition of natural numbers is incorporated into a broader pedagogical context.
\end{abstract}

Otroci z zmanjšano kognitivno učinkovitostjo in seštevanje naravnih števil do

Raziskava obravnava poučevanje in učenje seštevanja naravnih števil do $20 \mathrm{v}$ prvih dveh letih osnovne šole. Prvi del predstavlja teoretska izhodišča za seštevanje naravnih števil, postopkovni in pojmovni pristop $\mathrm{k}$ seštevanju ter teorijo seštevalne triade. Očrtani so vzroki težav, ki jih imajo nekateri otroci na področju seštevanja naravnih števil, vprašanje zmanjšane kognitivne učinkovitosti pa je na kratko predstavljeno kot eden od teh vzrokov. Drugi del raziskave predstavlja študija primera deklice (stare 7 let), ki je pri učenju seštevanja imela težave. Opisani so pristopi in rezultati popravnega vodenja deklice. $V$ razpravi je vprašanje seštevanja naravnih števil vključeno $\mathrm{v}$ širš̀ pedagoški kontekst.

\footnotetext{
DOI https://doi.org/10.18690/rei.14.2.125-148.2021

Besedilo / Text (C) 2021 Avtor(ji) / The Author(s)

To delo je objavljeno pod licenco Creative Commons CC BY Priznanje avtorstva 4.0 Mednarodna. Uporabnikom je dovoljeno tako nekomercialno kot tudi komercialno reproduciranje, distribuiranje, dajanje $\mathrm{v}$ najem, javna priobčitev in predelava avtorskega dela, pod pogojem, da navedejo avtorja izvirnega dela. (https://creativecommons.org/licenses/by/4.0/).
}

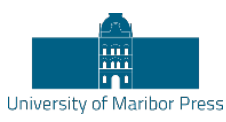




\section{Introduction}

One of the tasks of younger school-age pupils is to master the operations of adding natural numbers. According to the Czech Framework Educational Program for Elementary Education [Rámcový vzdělávací program pro základní vzděláváni] (Research Institute of Education in Prague, 2007) (FEP), the recommended level of achievement in the first period of primary education, is that the pupil perform simple memorized numerical operations with natural numbers, while the minimum recommended level is that the pupil adds and subtracts up to 20 using visual aids. In performing these operations, pupils master various numerical strategies. One possible strategy is to master the basic terms of addition in the field up to 10 and the breakdown of numbers up to 10 , which allows them to solve the more demanding subsequent tasks involved in adding up to 20 . The range of strategies that pupils may encounter is wide. Not all strategies succeed with certain groups of pupils, and some pupils may have difficulty even acquiring the ability to add up effectively.

This article aims to illustrate by means of a case study the problems pupils can face and how difficult it can be for them to manage the addition of numbers in the field up to 20. This issue lies within the didactics field of mathematics and is discussed in connection with the issue of reduced cognitive effectiveness, based on developmental psychology. The case study aims to accompany the theoretical explanation, i.e., to illustrate the issue with examples. The authors believe that this text (including the case study) could be useful not only for teachers and counsellors in education, but also for tutoring, a developing area of pedagogy. The authors emphasize that professional knowledge of the mathematical-didactic, pedagogical, and psychological fields cannot be underestimated in this area.

\section{Addition of natural numbers: Mathematical background}

\section{Addition of natural numbers with a transition - procedure or concept?}

Whether dealing theoretically or practically with the issue of teaching the addition of natural numbers in a child's early school years, the first question to answer is whether addition is more of a procedure (i.e., the procedure by which we add through automated terms, etc.) or a concept (i.e., understanding the addition operation, its properties, etc.). It is necessary to consider whether one precedes the other, or both occur simultaneously, whether there can be a procedure without a concept or, conversely, a concept without a procedure. 
Jonsson et al. (2014) considers the need for an algorithm; the importance of an algorithm is that it can be determined in advance, and the execution of an algorithm is associated with high reliability and speed. However, the algorithm can be recalled in its original form without any conceptual understanding of it (Jonsson et al., 2014). First, the beginning of the process of addition teaching is described. In mastering the addition procedure, the pupil becomes familiar with and then learns the meaning of the operation through the manipulative activity of grouping elements together and observing what happens when a single group of elements is created out of two groups. Only then does the pupil understand the process and begin to use the symbolic notation with the characters + and $=$. By working through simple exercises, the pupil learns the basic connections. At this point, addition is a process for the pupil to observe and try to memorize. In the learning phase of the process, it is useful when a pupil forms an opinion, although each operation can be simply learned as a procedure without imagination or creativity. A number can be viewed either as a cardinal number (pupils work with objects and put them together) or as an ordinal number (pupils work with order and can learn it, for example, by stepping on a stepping strip). Then, through certain mechanisms, which we will mention below, the pupil learns the individual procedures needed to handle addition. The procedure is important, but it should not be too mechanical. The idea is to allow the pupil to understand the operation and gradually create the concept of addition. Hejný (2014) introduced the concept of an additive triad, which the pupil should aim at during the learning of addition. In the next section this concept is introduced in more detail.

\section{Additive triad - basic concept of arithmetic}

According to Hejný (2014), school arithmetic overemphasizes the processes of adding and neglects the development of conceptual approaches. "As a result, the pupil is not able to see the problem as a whole, and his/her solution strategy consists in finding the part of the problem for which he/she has calculative procedures in the memory" (p. 94). To achieve the conceptual perception of arithmetic by pupils in the case of natural number addition, we aim to see the calculation of $\mathrm{a}+\mathrm{b}=\mathrm{c}$ not only as a process but also as a concept, as a trinity (a, b, c), which Hejný (2014) calls the additive triad. While the procedural aspect of mathematics focuses on the routine manipulation of objects, conceptual knowledge is knowledge-rich in relationships. For example, Hiebert and Lefevre (1986) describe conceptual knowledge as interconnected information rather than isolated information. 
Gray and Tall (1994) use the term procept to indicate the combination of process and concept and state that the counting process is encapsulated in the concept of number. There is no doubt that, at the beginning of acquiring addition skills, the pupil goes through a procedural stage in addition. This is a demanding job, where the pupil absorbs important operations and tries to store them in long-term, usable memory so that he/she can solve more demanding tasks with the help of these automated operations. The cognitive and time-consuming nature of this activity seems to have led to the belief that memorization is harmful and counterproductive for pupils. Pupils who needed to count without the help of automated combinations most often counted one by one. This is a lengthy and difficult strategy to transfer to more demanding tasks, such as $23+48$. Despite a child's ability to absorb new knowledge, making these early combinations is a challenging and long-term activity. One methodology recommends automating all combinations up to ten and then combinations with transitions above ten (e.g., Hruša et al., 1962). Another frequent recommendation is to discuss subtraction almost simultaneously with addition, although many children may have difficulty understanding two operations at the same time. As documented in the literature (Blažková, 2017, pp. 71-73), if the pupil is equipped with automated addition combinations up to 10 and with a transition to 20 , it is possible to gradually deviate from the procedure and move towards conceptual understanding of addition. Let us demonstrate the difference between the procedural and conceptual approaches. The instruction for the addition of $7+$ $6=\ldots$ is purely procedural. The pupil need only find the right connection in his/her memory, or in the worst case, can do the calculation one by one. The pupil is in a more difficult situation if the task is presented as $7+\ldots=13$, verbally "seven and how many equals thirteen?" Addition is a simpler operation than subtraction, so if the pupil does not want to convert the task to subtraction, they need to find the combination " $7+6$ " in memory. Again, it is possible to calculate one by one.

The task $7+6=13$ hides four equivalent tasks:

$$
\begin{aligned}
& 7+6=13 \\
& 6+7=13 \\
& 13-6=7 \\
& 13-7=6
\end{aligned}
$$

Here we are quite close to conceptual understanding and the additive triad $(6,7,13)$. 
At the same time, if pupils are only at the level of process understanding, and have not mastered this subject conceptually, they see the tasks $6+7=\ldots, 6+\ldots=13$ a $13-\ldots=6$ as three completely unrelated tasks. The aim is for the pupil to understand that it is the same modified task and therefore to develop a conceptual understanding. Automating combinations can help some pupils gain conceptual understanding. For some pupils, automation never occurs, while conceptual understanding comes almost immediately, as mentioned above. There are also pupils for whom there is neither automation nor conceptual understanding. It is necessary to work individually with each pupil in these groups and understand their particular situation.

\section{Different strategies for mastering addition}

There are several approaches for pupils to master the goal of adding natural numbers. We will mention the most common ones here.

1. Counting one by one. This is the least cognitively demanding strategy, the results of which are the least useful in other subjects. Two commonly used counting procedures, whether children use their fingers or not, are termed counting-on or counting-all (Fuson, 1982; Groen \& Parkman, 1972). The counting-on procedure typically involves stating the larger valued addend and then counting a number of times equal to the value of the smaller addend, such as counting 5 , $6,7,8$ to solve $5+3$. Counting all involves counting both addends starting from 1. The development of procedural competences is related, in part, to improvements in children's conceptual understanding of counting and is reflected in a gradual shift from frequent use of counting-all to counting-on (Geary \& Hoard, 2005).

2. Memory acquisition of combinations up to 10, then decomposition of numbers. This is a very cognitively demanding strategy. Its goal is to master all addition combinations up to 10 and all decomposition combinations, which allow the solution of more demanding tasks. Knowledge is formed cumulatively (it piles up on top of each previous item), and it is necessary to work with orders.

3. Addition according to arithmetic patterns - Gaidoschik (2015) describes this strategy as "addition without counting". For example, the pupil has to calculate $3+4$ and remembers the supporting connection of equal sums $3+3=6$. He can, therefore, use this known connection to determine "without counting" that $3+$ $4=7$. In this strategy, pupils use various schemes and formulas that make it easier for them to make calculations. 
The method of arithmetic patterns is also used in research by Ellemor-Collins and Wright (2009). Sharma (2015) also states that using visual clusters allows some pupils to search for relationships between numbers.

4. Alternation of previous strategies. The pupil can alternate these strategies in different ways. Some combinations are automatic; for other combinations, they use a known formula (typically $4+9$ calculated as $4+10-1$ ), and in situations where it is necessary under stress, they calculate one by one.

For optimal support of the learning process, it is necessary to know which strategy suits which child. Hence it is beneficial to offer a range of strategies for children to learn. However, a problem occurs when strategies are not offered purposefully and systematically. For example, the child may encounter one strategy in mathematics lessons, another strategy in tutoring, another in home preparation with his parents, and an assistant teacher may also come into play. In this case the strategies are mixed, and the child becomes confused.

There are many international research studies concerning the use of these different addition strategies. Some compare the teaching of addition in different countries; for example, Fuson and Kwon (1992) compared teaching in the United States and Korea, to examine why Korean pupils were achieving greater addition skills than American pupils. The authors suggested one explanation might be the Korean way of marking numbers above 10 with the terms "ten one, ten two," etc., which allows pupils to more easily perceive the quantity in each order (Strategy 2). A second reason might be that Korean pupils (but also Chinese, Japanese, and pupils from other Asian countries) learned to add over base 10 employing decomposition, e.g. $8+6=8+2+4=14$ (read "ten four"). In addition, Korean pupils used their fingers to add numbers with a transition above the base of ten.

Japanese pupils have also shown great success in addition (Murata \& Fuson, 2001). One of the strategies that Japanese 1st and 2nd graders use extensively is counting to 5 or decomposing the number 5 (varied Strategy 2). Using this strategy with the example of the $4+4$ task, the pupils often proceeded by adding 1 to four and at the same time subtracting one from four, because $4+4=5+3=8$. Similar thought processes were involved when solving more demanding tasks, where instead of the number 5 , they worked with the number 10 . When calculating $7+7$, they thought as follows: seven is missing 3 from 10, so they subtract 3 from 7 and add 3 to the second 7, i.e., $7+7=10+4=14$ (Murata \& Fuson 2001). This strategy is similar to our strategy based on decomposition of the number 10 . 
For example, one study examined Korean pupils who were taught arithmetic patterns (finger use) and number decomposition in addition teaching and found that these pupils were very successful in addition tasks, as well as using more sophisticated solution strategies, such as memorial addition or use of a known fact (e.g. $6+7=6+6+1$, where $6+6$ is a known fact). Japanese pupils also showed high success in counting in the first two years of primary school, and studies report that pupils spend many hours at the beginning of the first grade on decomposition of numbers below 10 and auxiliary calculations based on counting to 5 or 10 or decomposition of 5 and 10.

In the Czech context, Blažková (2017) discusses in detail the strategy where the numerical operation of adding natural numbers is based on manipulation of objects, meaning that we group objects put them together, add them, etc. Previous strategies may be based on this approach when pupils work with objects. Pupils gradually master the memorized combinations of addition in the field up to five, ten, twenty, and one hundred. Blažková (2017) draws attention to the greater complexity of some combinations in the field up to 10 , because the $8+2$ task is usually easier for a child than the $2+8$ task.

At this point, the child should start using addition commutativity for easier memorization. Gaidoschik (2015) maintains that this is one of the principles that should be used in learning "addition without counting." For addition in the field up to twenty, the child must also be able to decompose numbers. For example, $8+7$ is most often taught as $8+7=8+(2+5)=(8+2)+5=10+5=15$. The second addend will therefore be decomposed to complete the first addend by 10 . Blažková (2017) notes that such decomposition can be challenging for many pupils, so it is replaced with other strategies. E.g., $8+7=(5+3)+(5+2)=(5+$ $5)+(2+3)=10+5=15$, i.e., both sums are decomposed by the number 5 . This procedure involves several steps, as the child compensates for his difficulty in coping with the learning situation by seemingly "complicating" the solution and may take longer to complete the task. Such processes can then be qualified as a consequence of reduced cognitive effectiveness, which is discussed in the following section. 


\section{Limited cognitive efficiency and working memory: Psychological background}

It is apparent from the previous discussion that the learning of addition (and later subtraction) is not as easy as it may seem at first glance. In addition, the dynamics of the development (maturation) of younger school-age children and possible specific learning difficulties need to be considered. Various external and internal (subjective) factors can cause pupils to fail to learn to count with the transition over ten.

In pedagogical and counselling practice, the term cognitive efficiency is used to refer to the extent and time frame in which the child deals with the concurrence of demands of a learning task (cf. Hoffman, Schraw, McCrudden, 2012), which often has to be achieved in a short timeframe. This leads to the situation where the pupil does not manage to solve the problem or does not solve it in the correct sequence and leads to errors in procedures and results. Hence, cognitive congestion (overload) can occur in pupils, especially in the initial stages of learning. This cognitive congestion in addition learning can be explained by the general theory of flexible resource allocation (Kahneman 1973). This theory explains how our attention functions when we process a lot of information in parallel. In principle, a person has only a limited range of cognitive resources that can be used in information processing (cf. Lukesch 2001, pp. 61-64). If the demands of a particular task are high, and especially if some stages are difficult, all available resources are used in the problem solution. If, at the same time, some other aspect of the task requires the use of resources, these will no longer be available. This leads to failure, and in school such a situation manifests itself in "tasks solved only partially". The theory of flexible resource allocation has been well developed into a didactic position. In relation to learning, it means (1) developing "selective attention", which is the ability to focus attention on essential aspects of the task and perceive insignificant aspects as marginal, and (2) learning to properly allocate available cognitive resources (implement a "sourcing strategy"). Memory is important in the learning process which is successful when the pupil has mastered certain parts of learning something (e.g., solving mathematical tasks) at the level of routine procedures (i.e., memory). This allows pupils to save their cognitive resources and use them at the more difficult stages. This is often the key to successful problem solving. In short, children need to be helped to manage their cognitive, motivational, emotional, and other resources, especially when they seem to have fewer of these at their disposal. 
We use a combination of long-term and short-term memory when adding two numbers, where we activate known combinations in long-term memory (e.g., $3+7$ $=10$ ), and the short-term memory must maintain all auxiliary calculations. The term working memory is sometimes used for short-term memory to emphasize its role in thinking, rather than its warehouse function (cf. Nolen-Hoeksema et al. 2012). Working memory plays an important role in the thinking involved in solving mathematical problems. Nolen-Hoeksema et al. (2012, p. 332) state: "When one consciously tries to solve a problem, one often uses working memory to store part of the problem. It also uses information retrieved from long-term memory that is somehow related to the problem. To illustrate, imagine that you have to memorize $35 \cdot 8$. You need working memory to memorize the entered numbers (35 and 8 ), the required operation (multiplication), and arithmetic data such as $8 \cdot 5=40$ and $8 \cdot 3=$ 24." It can be seen from this example that, when performing a mathematical operation, the pupil's memory is relatively busy. If the pupil has not sufficiently mastered the basic combinations, the working memory may be overloaded. Another source of difficulty in solving even seemingly trivial tasks is when a child has a reduced working memory capacity. Working memory capacity in general is limited. It has been shown that most people can keep the items $7 \_2$ in memory for a short time (Nolen-Hoeksema et al. 2012). Under certain circumstances, when information is repeated or processed in other forms, information is shifted from short-term to long-term memory. The capacity of long-term memory is considerable, to the extent that some psychologists maintain that it is unlimited, e.g., Nolen-Hoeksema et al. (2012). However, most information is forgotten very quickly. Long-term memorization is supported by repetition, but this can seem boring or overwhelming to pupils. However, memory can be improved by creating real or artificial connections between individual items (Nolen-Hoeksema et al. 2012). For example, Maria Montessori maintained that memorization in mathematics could be supported by using multiple senses i.e., by multisensory learning (Feez 2010). Montessori created didactic material so that the child could work with shape (touch) or colour (sight). The child may have trouble remembering that " $2+4=6$ " and it may be easier to remember that "green plus yellow equals purple". The child uses multiple senses, for example, when working with coloured beads during addition. The child visually perceives the arrangement of the beads (shape scheme), also their colour, and can perceive the amount by touch. Hence multisensory learning can be an effective strategy for some children, and it has become one of our important principles in the intervention described below. 


\section{Pedagogical consequences: Towards an intervention}

Certain conclusions can be drawn from the text presented above for the design of interventions to compensate for these problems. If the goal is to pedagogically support younger school-age pupils (e.g., in the form of tutoring) who have problems with addition and with the transition to numbers over 10, compensatory learning procedures should do the following:

(1) Identify that part of the task where the pupil began to have problems. This can be difficult for teachers in a large group of children, and it requires individual diagnostics. It is necessary to differentiate the tasks according to the difficulty (Hejný 2014) and to monitor the pupil during the solution.

(2) Work with limits to task difficulty. After having identified the pupil's problem, the tasks are chosen to work with what the pupil knows and to target the problem phase.

(3) Provide more clarity and structure when dealing with learning tasks - using various representations and manipulatives to improve understanding of concepts and procedures.

(4) Involve elements of multisensory learning. Using multiple senses can help the pupil overcome difficulties that block memorization and comprehension. If the pupil has the capacity to manage that, it can lead to gradual improvement.

These principles were followed in an intervention with a girl described in the case study below. Because the girl, in the second year of primary school, lacked the basic knowledge and skills for addition, a strategy had to be identified that would lead relatively quickly to the goal. The methodology used was therefore carefully thought out and selected, based on our experience of working with pupils with similar problems.

\section{A Case Study: Research methodology and pedagogical intervention}

We - as teacher educators and researchers - are committed to combining two approaches in our work: (a) we develop supportive learning environments and learning tasks, and (b) we do research in this field. One way to document and share these activities within the professional community of teachers is a case study (Janík et al. 2019). A case study was chosen here as the research approach, more precisely, a descriptive and instrumental case study (cf. Mareš 2015). 
In the descriptive function, a case study is used "to describe in detail, a comprehensive phenomenon of real life in the context in which it commonly occurs and takes place" (Mareš 2015, p. 121). In our case, it was a problem of reduced cognitive effectiveness in learning addition in the field up to 20 with a transition over base 10. In the instrumental function, the case study represents a particular case of a general phenomenon to "understand the theoretical questions such as how and why it works in real life" (Mareš 2015, p. 121). In our case, we captured the specific forms of the problem of this pupil's reduced cognitive effectiveness.

The framework of the case study was guided by these questions: (a) What strategies are used by the pupil in solving the tasks before the intervention? (b) Are there changes towards more sophisticated strategies during the intervention? Data for the case study were collected over five months while the pupil was attending the 2nd year of primary school. The data set included interviews with parents and teachers, the pupil's problem-solving tasks captured in workbooks and the pupil's verbal descriptions related to the solution strategies she used. A video of each intervention was recorded, and other contextual information (such as finger use, gestures, facial expressions) was documented. Information for analysis was selected from this extensive data set. In addition to its cognitive aspects, the case study was intended to fulfil a didactic function in that it represents an enrichment of pedagogical practice (cf. Slavík, Stará, Uličná, Najvar, et al. 2017). This should be ensured by capturing "the development of the case in the form of a specific narrative - the story of clinical practice" (ibid p. 22). In the next section, we present the story of clinical practice, in which we, in the dual role of teachers and researchers, tried to help the child overcome the problems caused by reduced cognitive efficiency in learning addition.

In the case of... Patrika (7 years old) (a pseudonym is used)

Patrika's parents, after a difficult experience with their first daughter in a traditional elementary school, decided to place their second daughter in a recently created alternative (private) school. Teachers here presented themselves as "guides", whose task is not to provide teaching but to help children discover the world. These "guides" were enthusiasts who were experts in various non-pedagogical fields and had a very positive attitude to children, but they were not sufficiently familiar with the didactics of particular school subjects and the cognitive processes of children. 
Their lack of pedagogical knowledge and skills meant that they were unable to respond flexibly to their pupil's needs, did not recognize various phenomena appearing in the classroom, refused to reflect on the needs of pupils described in reports from pedagogical-psychological counselling, etc. Problems emerged during the first year of Patrika's education at this school. At first, the parents noticed that Patrika did not make the usual progress in adding up numbers. When they investigated Patrika's workbook, they found no entries. Then they tried to find out how addition was taught at the school. They discovered that pupils stepped on the walking strip but that they did not have to write if they did not want to, and they did not receive any homework.

When it became apparent that Patrika was falling behind, the parents turned to the pedagogical-psychological counselling centre. They learned that, while Patrika showed strong verbal abilities, she also showed reduced effectiveness of cognitive processes (concentration problems, reduced pace, poor performance in working memory) An individual education plan was recommended for Patrika with procedures designed to lead to compensation. When the parents asked the school to come up with an individual plan, they were told that they "did not follow official papers". The parents decided to change schools. They chose a rural school with a "traditional approach" to teaching and learning. However, if Patrika was to succeed, she had to catch up on the missed curriculum. During the summer holidays, the parents and daughter worked together for approximately three hours per day, not only with counting but also writing. Progress was slow, and a lack of working and learning habits created additional issues of concern. Her second-year teacher at the new school made the usual demands of traditional schooling in terms of curriculum. Patrika was not at the same level as the other pupils, and mathematics lessons were especially challenging and worrying. Her most frequent strategy when adding up was counting one-by-one. That strategy failed when she was under time pressure, became tired or lacked concentration, and Patrika guessed the answers.

\section{Analysis of Patrika's difficulties}

The lead author of this paper began tutoring Patrika with the aim of creating a better understanding of the concept of a number and fixing in memory the operations needed for addition by visualization and manipulation. As stated above, Patrika was using a one-by-one counting strategy in most cases, and only a few combinations had been memorized (e.g., $3+3$ ). 
Following the case study framework above, the tutor began by assessing the strategies in use in Patrika's classroom. Addition with the transition was taught with the use of "splits", in which the second addend is decomposed so that the first addend is added to 10. In Figure 1, we can see how demanding this representation may be for some pupils. The pupil has the split from the second addend, the first addend and the first number from the decomposition is on a yellow background this is to emphasize that these two numbers should have a sum of 10. What was intended to be simple was quite confusing for children like Patrika. In this case, Patrika added up by counting one-by-one and we can see that she made a mistake in all the calculations she worked on herself (in the first three cases she was assisted by the teacher). Some calculations are very striking - for example, in the last case she writes $9+9=9+1+1=11$.

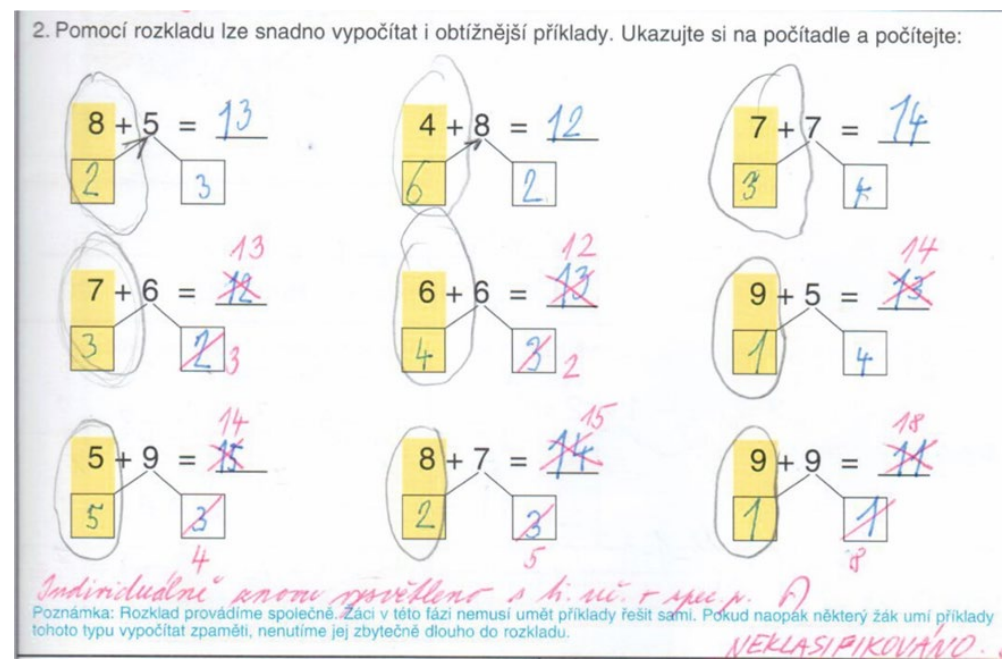

Figure 1: Patrika's difficulties with decomposition of the second addend.

Strategies were alternated in the school's textbook, and we encountered a different representation of the decomposition of the second addend. Figure 2 shows a representation using a rectangle with dots. After ten dots, there is a red line showing the number ten. What would benefit other pupils, was rather harmful to Patrika. She did not know how to follow the scheme and only respected the decomposition strategy if the teacher worked with her. In other cases, she continued to count oneby-one. 


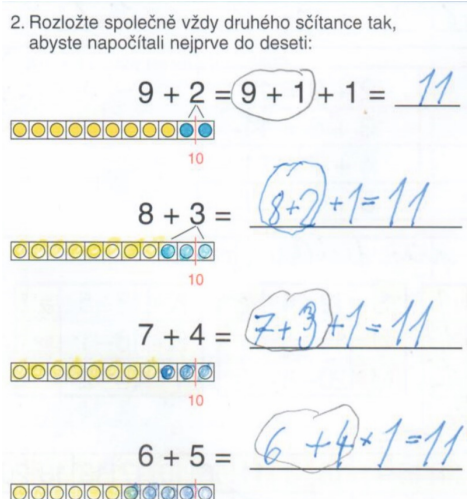

Figure 2: Displaying decomposition of the second addend

For Patrika, the most demanding representation of addition was using a numerical axis, which was incomprehensible to her, and she was unable to follow at all. Figure 3 shows this procedure. The example $4+7$ is solved by displaying the image of the number 4 and then making 7 arches to the right. However, it is the image of a number on a line that is difficult to understand and imagine for so many pupils.

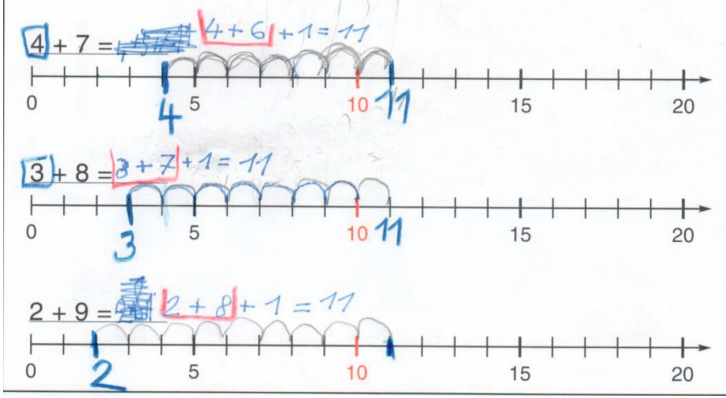

Figure 3: Addition on the numerical axis

At that time, Patrika was also supposed to be dealing with subtraction at school. Since she did not have a clear idea of the addition operations and had no stabilized combinations, subtraction was just another aggravating activity for her. The tasks of adding up to certain numbers and subtracting was generally wrong, as shown in Figure 4, even though she proceeded with the one-by-one counting method. For example, in the case of $13-7=7$ Patrika counted on her fingers one-by-one as follows: $13,12,11,10,9,8,7$. This mistake, where the result is higher by one, is frequently made, as pointed out by Blažková (2017). 
Interesting but more difficult to explain are the cases $12-9=10$ and $12-8=18$. It can also be noted that on one line, Patrika filled in different numbers, although it is a modification of the same example (e.g. $13-9=4$ and $9+4=13$ on the first line). The intention of the task, to simplify subtraction through adding up, was thus missed.

$$
\begin{aligned}
& \text { 3. Pozoruj. Co je snazši? } \\
& \text { Vypočítej nejprve dočitáním, pak } \\
& \text { dopiš výsledek do 1. sloupce: } \\
& 13-9=8 \quad 9+66=13 \\
& 13-7=\not 2 \quad 7+\not 2=13 \\
& 13-8=\frac{g}{2} 8+\underline{4}=13 \\
& 12-9=10 \quad 9+\underline{3}=12 \\
& 12-8=18 \quad 8+4=12
\end{aligned}
$$

Figure 4: Patrika's difficulties with addition and subtraction

Based on the analysis, special tutoring for Patrika was developed by the first author of this paper. The four principles listed above were respected.

\section{Tutoring in two stages}

This section describes the methodology used in tutoring a seven-year-old girl (Patrika), who had difficulty learning addition and subtraction with transition, probably owing to reduced cognitive efficiency. The main tool used is shown in Fig. 5 and Fig 7. It consists of grids and beads because in our experience the idea of a natural number as a cardinal number is important for a child. The problem, however, is that a number of five or more beads in a pile can only be determined by either arranging them in a written grid with 10 columns and one row or counting them one by one. For this reason, our tool also includes the arrangement into shapes, and the objects have their order (ordinal perception of the number).

\section{Stage 1}

The process began with the pupil learning to add natural numbers in the field up to 10 . Opinion and manipulation are essential in the activity. During the addition, the two addends are represented by two different colours of beads as in Fig. 5, where the calculation $2+5=$ 7 is demonstrated. The child puts the beads into the grid one by one and can also perceive the colour and shape scheme - and so has the opportunity to view the process in several ways. The pupil can also write down the results to support the activity.

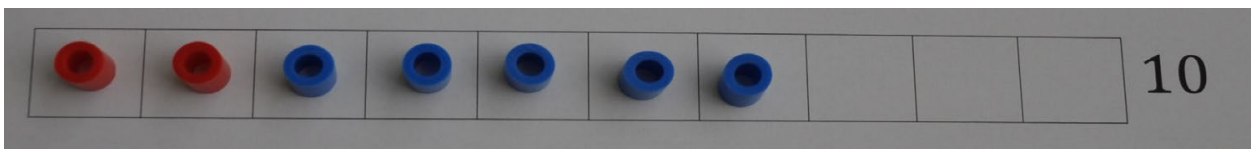

Figure 5: Grid with beeds - using colours when adding up to 10 
If the child noted all combinations up to 10 , a memory acquisition had occurred. In our experience this activity usually took two weeks. At the same time, the tutor used various strategies to avoid boring the child with endless repetition. For example, colouring books with examples were used (colour corresponds to one result), addition pyramids, oral examination ("two plus five equals"), and later addition ("two plus how much equals seven?"). The speed of the connection is important, but it was necessary to give the pupil as much time as they needed so that they were not stressed. For example, pupils with dyslexia need more time for calculations than pupils without learning difficulties.

Examples of addition pyramids are shown in Fig. 6. On the left is a pyramid with the sum of $2+9=\ldots$, on the right is a pyramid for the addition of $6+\ldots=14$. While for the average child the second option may be only slightly more challenging than the first, mathematically weak children or children with learning disabilities may have great difficulty learning the hidden symbolism.
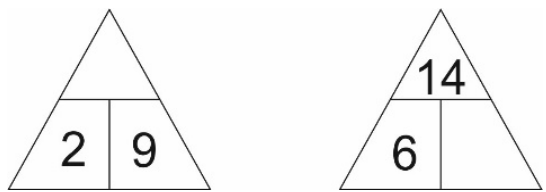

Figure 6: Example of addition pyramids

Decompositions of the number 10 are essential at this stage and thus receive special emphasis. The pupil writes them out separately and learns them by heart. An effective strategy is adding to 10 out loud: the teacher says the number and the pupil says the other number, so the total sum is ten. For example, the teacher says 3, and the pupil answers 7 .

\section{Stage 2}

The next phase is addition with the transition over the base 10. The acquisition of combinations helps when the pupil uses colour schemes and manipulation. A grid with beads was again used. Tasks were chosen with a result up to 20. Beads of two colours are chosen and placed in a grid. The procedure for calculating $7+5=\ldots$ (Fig. 7 ) is shown. Seven beads of one colour are placed on the first grid from the left followed by five beads of the other colour. When the top grid of ten is full, the beads are added to the next grid (second ten).

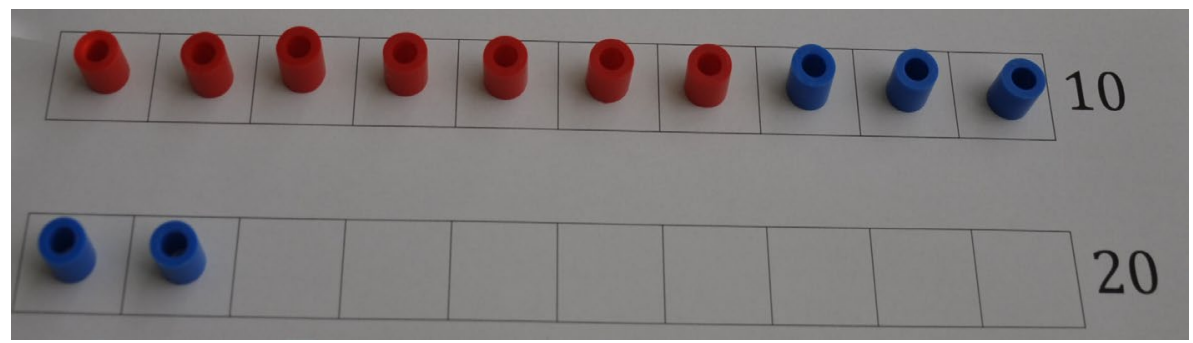

Figure 7: Grid with beeds

What is shown in the grid? 
1) Decomposition of the number $10(7+3=10)$.

2) Decomposition of the second addend to complete the first to $10(5=3+2)$.

3) Overall result $(7+5=7+3+2=10+2=12)$.

The pupil works not only with numbers but also with colour and patterns. This facilitates the process of memorization and automation. Shape and colour memory are used; therefore, the potential for multisensory learning is implemented. These processes are described in the case study below.

\section{Analysis of Patrika's learning during 2 stages of tutoring}

During three weeks of tutoring, plus the regular work of the teacher and assistant teacher at school, efforts by the parents, and Patrika's daily practice, some progress was observed. In some exercises Patrika started to replace the adding up strategy of one-by-one with the decomposition strategies which she had learned through a grid with beads. In some cases, she still counted on her fingers. The error rate fell but did not decrease to zero. While Patrika celebrated her first partial success in the addition of numbers, more and more content was introduced in the school such as subtraction and addition pyramids. These pyramids were problematic for her. For her to successfully solve a pyramid problem, Patrika had to have mastered the whole additive triad, although she was only starting to manage addition. Though the teacher explained the relationships in the pyramid many times, Patrika was overwhelmed with the load of information, as shown in Fig. 8, and in desperate efforts to solve the problems, she invented solutions that she could even justify.

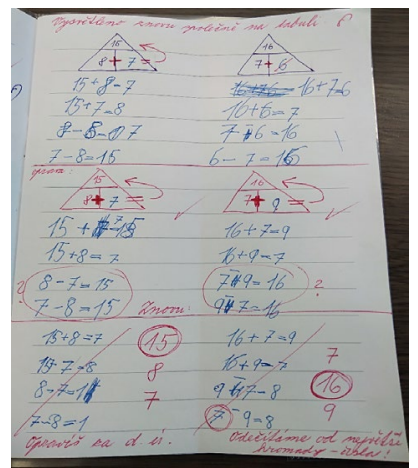

Figure 8: Patrika's problems with addition pyramids

Examine how Patrika considered the pyramid with numbers 15 and 8 (in Fig. 8). She knew that there were three numbers in the pyramid $(7,8,15)$ and that she was to find four examples. She could not make other connections, however, because she did not understand the relationship between the numbers. The teacher's effort to 
graphically emphasize operations was not effective. Patrika was supposed to come up with four tasks, two for addition and two for subtraction, so she invented them and was not bothered by the fact that her answers did not make sense (she didn't even think about sense at all); for example, $7-9=16$ or $7-8=16$. The girl was exposed to procedurally oriented teaching approaches, and that is probably why she tried to use these procedures in solving other types of tasks. As previously stated, Patrika used different strategies for addition. However, there was no system to their use, and it was not clear what types of examples were associated with which strategies. Patrika was filmed during her tutoring lessons and the transcripts of the lessons demonstrate how Patrika worked. The text features T (tutor) and P (Patrika).

\section{Example 1}

T: "Let's try $6+8$. ."

P: A few seconds of silence. "Thirteen."

T: "How did you count that, Paty?"

$\mathrm{P}$ : "That six plus six is twelve and that six plus eight is thirteen."

T: "Hmm, but eight is two more than six. So, it would be two more than twelve."

P: "Oh, fourteen."

In this recording, we see that Patrika used an automated joint $6+6=12$, called "the lighthouse" by Hejný (2014), and then made the mistake of adding only one unit from six to eight. This error can frequently be seen in children walking on the walking line or playing Ludo. In Ludo, we see a child with the number 5 on the dice connect "one" with the position on which they stand. The child does not count the number of steps (changes), but rather the number of fields, including what should be the "zero" field. Sometimes it was obvious that Patrika had her fingers resting on the table, moving them gently while counting, but imagining them in her mind. She did so because she was not encouraged to use her fingers at school, but needed them as support, so she used them covertly. Keeping the whole process in memory was difficult for her, so she made more mistakes. The tutoring goal was to teach Patrika gradually how to use the decomposition of numbers and adding to dozens. The first strategy she chose was usually one of her older strategies (often finger imagination), which resulted in a poor outcome; then she was asked to use decomposition (see example 2). 
Although decomposition was much more certain for her as to the accuracy of the outcome, she still reverted to more deep-rooted strategies (See example 2).

\section{Example 2}

T: “7 + 8”

P: A moment of silence, she counts in her mind. "Eighteen."

T: "No. Let's try it by decomposition."

P: "Seven plus eight, I'll add three, and I still have five."

T: "So?"

P: "So fifteen."

\section{To sum up}

During the intervention, we documented Patrika's learning achievements, her ability to solve problems etc. Based on routine diagnostics, we observed that by the end she showed fewer errors than at the beginning, as well as errors of a different nature. While at the beginning she guessed more about the results, at the end she was able to use the number decomposition strategy more, although not reliably. Her error rate decreased significantly. While Patrika was dealing with addition over 20, her classmates were subtracting and solving even more demanding pyramids. However, if Patrika was to achieve lasting improvement, it was not possible to speed up the cognitive process. It was clear that Patrika's current skills and the curriculum being taught at school were in conflict. It was recommended that Patrika solve only pyramids with examples of the type $5+6=\ldots$. It was also recommended that Patrika slow down the pace of her learning because she was unable to proceed as quickly as her classmates with the curriculum. Moreover, while her classmates managed to perform addition and subtraction simultaneously, it was important for Patrika that the operations were separated from each other until the operations became more stable. However, it still was not over for her. At school, subtraction, and addition of two-digit numbers had been taught for some time. Understanding the orders in the number was another big challenge for Patrika. While Patrika seemed to have overcome her issues and succeeded in adding up, multiplication was to be taught. The whole process began to repeat; with a new operation, Patrika's addition links were destabilized. She had to face another difficult task.

Patrika was finally successful in understanding the addition operation and stabilizing some combinations during tutoring, which lasted about six weeks. 
In answer to the second question of the case study, the intervention had resulted in Patrika developing more sophisticated strategies.

\section{Discussion and conclusions}

When a child learns a mathematical operation, they should master both procedural skills and conceptual understanding. In the case study, we looked at a girl who had difficulty with both components. As Hejný (2014) emphasized, children are different; they reach the same goal in different ways and at different speeds. A necessary precondition for such an approach is the need to adapt the process to the individual. If the child is unable to grasp the concept of the additive triad or even unable to handle the necessary procedures as quickly as their peers, it is necessary to proceed to individual education that is tailored to the child. This is difficult if the heterogeneity of pupils in the classroom increases. If the pupil cannot manage addition in the field up to 10 or addition with transition in the field up to 20 , this often results in problems that accompany the child throughout their remaining school life, unless the child is able to catch up with the corrective mechanisms. Sharma (2015) states that when children do not automatize facts, they are unable to apply their knowledge to newer situations. To find the answer to a number problem, they digress from the main problem to generate the facts needed for solving problems. Because of the use of inefficient strategies, such as counting, their working memory space is filled in the process of constructing these facts; it is thus not available to pay attention to focus on concepts or relationships etc. (Sharma, 2015). When the methodology was developed for tutoring Patrika, the assumption was made that it was critical to emphasize arithmetic patterns and understand decomposition and addition up to 10, as our experience and some scientific studies suggest. For example, Fuson and Kwon (1992) examined Korean pupils, who were very successful in adding and used fingers for patterns. Similarly, Japanese students were successful in adding and paid close attention to the decomposition of the number 10. In our case study, there was a big shift when the decompositions and patterns were used on Patrika, but apparently the reduced cognitive efficiency resulted in a slower pace of acquisition. Ellemor-Collins and Wright (2009) point out that some children, like Patrika, are unable to quickly and easily add numbers and insist on the least sophisticated strategy of counting one by one. With these children, the authors used the method of creating patterns. 
They achieved gradual progress with children, who were able to learn and continue to use some types of patterns. Our intervention with Patrika was also based on the principle of arithmetic patterns. Manipulative colour aids were used to involve multiple senses, thus supporting her memory. Although she quickly forgot new information, she managed to partially stabilize the combinations. Gradually, she also understood the addition operation itself, provided it was not burdened by any other operation (e.g., subtraction). With the implementation of a new operation, the created system always destabilized, and it took some time for the situation to settle again. In many methodologies and teaching systems, the recommendation is to teach subtraction in parallel with addition (e.g., Hruša et al. 1962). As a result of our study with Patrika, we do not recommend this procedure while teaching children with reduced cognitive effectiveness. Although most children can use the relationship between the two operations and learn both things at once, children with reduced cognitive effectiveness find that understanding the operation itself is a problem, learning combinations takes longer, and they are easily forgotten - probably due to cognitive overload, as discussed above. In some approaches, such as Montessori, it is common practice for operations to be implemented separately. After addition is stabilized (automatized) subtraction is introduced (see Feez, 2010). The case study focused on a girl with reduced cognitive efficiency and her attempts to manage the addition of natural numbers, together with the difficulties that accompanied it. The authors asked two research questions: (a) What were the problem-solving strategies used by the pupil in solving tasks before the intervention? (b) Were there changes in the use of solution strategies towards more sophisticated strategies during the intervention? The answer to the first question is that Patrika initially used a less sophisticated strategy of adding one by one, which failed when Patrika was stressed. As for the second question, during the intervention, an effort was made to accustom Patrika to a more sophisticated strategy, based on decomposition of the number 10 . As a result, Patrika learned to use this strategy, but still returned to the more familiar procedure of counting one by one and began to think about decomposition only when she was explicitly asked to do so. However, Patrika's self-confidence and numerical experience did gradually increase, leading to better success in addition. In her early school years, Patrika encountered various difficulties related to the current diversion from the traditional school, in which transmissive teaching and a unified methodology prevailed, which led pupils with the help of drills to a successful goal - automation of addition combinations, although often without the support of conceptual understanding. 
From our observations, we draw the following recommendation. When a child has problems with adding numbers, finds it difficult to remember the basic data and does not form correct ideas, it is advisable to prepare a strategy that will be clear, structured and adapted to the child. If he or she uses their fingers, it is advisable not to forbid it. It should be considered that the process will be gradual, and the difficulties will hinder further learning. Therefore, it is important to look for compensations that will help in overcoming the challenge.

\section{References}

Blažková, R. (2017). Didaktika matematiky se zamèrením na specifické poruchy uíení. Brno: Masarykova univerzita.

Ellemor-Collins, D., and Wright, R. (2009). Structuring Numbers 1 to 20: Developing FacileAddition and Subtraction. Mathematics Education Research Journal, 21(2), $50-75$.

Feez, S. (2010). Montessori and Early Childhood. London: Sage.

Fuson, K. C. (1982). An analysis of the counting-on solution procedure in addition. In T. P. Carpenter, J. M. Moser, \& T. A. Romberg (Eds.), Addition and Subtraction: A cognitive perspective (pp. 67-81). Hillsdale, NJ: Erlbaum.

Fuson, K. C., Kwon, Y. (1992). Korean children's single-digit addition and subtraction: number structured by ten. Journal for Research in Mathematics Education, 23(2), 148165.

Gaidoschik, M. (2015). Learning to compute without counting in first grade: A matter of patterns. Studia Scientifica Facultatis Paedagogicae Universitas Catholica Rǔ̌omberok, 14(2), $12-21$.

Geary, D. C., and Hoard, M. K. (2005). Learning disabilities in arithmetic and mathematics: Theoretical and empirical perspectives. In J. I. D. Campbell (Ed.), Handbook of Mathematical Cognition (pp. 253-267). New York: Psychology Press.

Gray, E. and Tall, D. (1994). Duality, ambiguity and flexibility: A proceptual view of simple arithmetic. Journal for Research in Mathematics Education, 26(2), 115-141.

Groen, G. J., and Parkman, J. M. (1972). A chronometric analysis of simple addition. Psychological Review, 79, 329-343.

Hejný, M. (2014). Vyučováni matematice orientované na budováni schémat: aritmetika 1. stupně. Praha: Univerzita Karlova, Pedagogická fakulta.

Hiebert, J., and Lefevre, P. (1986). Conceptual and procedural knowledge in mathematics: An introductory analysis. In James Hiebert (Ed.), Conceptual and Procedural Knowledge: The case of mathematics (pp. 1-27). Hillsdale, NJ: Erlbaum.

Hoffman B., Schraw G., and McCrudden M. T. (2012) Cognitive Efficiency. In Seel N. M. (Ed.), Encyclopedia of the Sciences of Learning. Boston: Springer.

Hruša, K. et al. (1962). Metodika počtui pro pedagogické instituty 2. Praha: SPN. 
Janík., T., Slavík, J., Najvar, P., Janíková, M., and Rusek, M. (2019). 3A Content-Focused Approach for Improving Instruction: Developing and Sharing Knowledge in Professional Communities. In T. Janík, M. I. Dalehefte, and S. Zehetmeier (Eds.), Supporting Teachers: Improving Instruction: Examples of Research-based Teacher Education (pp. 55-76). Münster/New York: Waxmann.

Jonnson, B., Norqvist, M., Liljekvist, Y., and Lithner, J. (2014). Learning mathematics through algorithmic and creative reasoning. Journal of Mathematical Behavior 36, 20 32.

Kahneman, D. (1973). Attention and Effort. Englewood Cliffs: Prentice-Hall.

Lukesch, H. (2001). Psychologie des Lernens und Lehrens. Regensburg: S. Roderer Verlag.

Mareš, J. (2015). Tvorba př́ipadových studií pro výzkumné účely. Pedagogika, 65(2), 113-142.

Murata, A., and Fuson, K. (2001). Learning paths to 5- and 10-structured understanding of quantity: Addition and subtraction solution strategies of Japanese children. In R. Speiser, C. S. Maher, and C. Walter (Eds.), Proceedings of the Twenty-Third Annual Meeting of the North American Chapter of the International Group for the Psychology of Mathematics Education, Vol. 2 (pp. 639-646). Columbus, OH: ERIC Clearinghouse for Science, Mathematics, and Environmental Education.

Nolen-Hoeksema, S., Fredrickson, B. L., Loftus, G. R., and Wagenaar, W. A. (2012). Psychologie Atkinsonové a Hilgarda. Praha: Portál.

Research Institute of Education in Prague (2007). Framework Educational Programme for Elementary Education. Retrieved from: http://www.nuv.cz/file/195 (Accessed April 29th, 2021).

Sharma, M. C. (2015). Numbersense: a window into dyscalculia and other mathematics difficulties. In Chinn, S. et al. The Routledge International Handbook of Dyscalculia and Mathematical Learning Difficulties. Routledge.

Slavík, J., Stará, J., Uličná, K., Najvar, P. et al. (2017). Didaktické kazuistiky v oborech školního vzdělávání. Brno: Masarykova univerzita.

\section{Acknowledgement}

In researching and writing this paper, the authors were supported by the grant on a Productive Culture of Teaching and Learning (Ga20-13038S) provided by the Czech Science Foundation.

\section{Authors}

\section{Dr. Irena Budínová}

Assistant Professor, Masaryk University, Faculty of Education, Brno, Poř́čí 31, Brno, 60200, Czech Republic, e-mail: budinova@ped.muni.cz

Docentka, Univerza Masaryk, Pedagoška fakulteta, Brno, Poříčí 31, Brno, 60200, Češka, epošta: budinova@ped.muni.cz

\section{Dr. Tomáš Janík}

Professor, Masaryk University, Faculty of Education, Brno, Poř́íći 31, Brno, 60200, Czech Republic, e-mail: tjanik@ped.muni.cz

Profesor, Univerza Masaryk, Pedagoška fakulteta, Brno, Poř́íčí 31, Brno, 60200, Češka, epošta: tjanik@ped.muni.cz 
